\title{
Allyl Alcohol Production by Conversion of Glycerol Over Supported Iron and Nickel Bimetallic Oxides
}

\author{
Nancy Martín ${ }^{1 *}$, María de Lourdes Rodríguez ${ }^{1}$, Dora Solís-Casados ${ }^{2}$, Margarita Viniegra $^{1}$ \\ ${ }^{1}$ Dept. Química. Universidad Autónoma Metropolitana-Iztapalapa, Av. San Rafael Atlixco $N^{\circ}$ 186. 09340 \\ CDMX, México. \\ ${ }^{2}$ Universidad Autónoma del Estado de México. Centro Conjunto de Investigación en Química Sustentable \\ UAEM-UNAM, Toluca, Edo. de México. México.
}

*Corresponding author: Nancy Martín, email: mgnc@xanum.uam.mx, Phone number: 525558044600 (x4317).

Received July $1^{\text {st }}, 2020$; Accepted September $24^{\text {th }}, 2020$.

DOI: http://dx.doi.org/10.29356/jmcs.v64i4.1246

\begin{abstract}
The study of catalysts based on iron, nickel, and iron-nickel oxides (Fe, Ni and FeNi) supported on a commercial mesoporous alumina is presented. The metal oxides were synthesized by the incipient wetness impregnation method. The samples were characterized by XRD, $\mathrm{H}_{2}-\mathrm{TPR}$, Raman spectroscopy, XPS and $\mathrm{N}_{2}$ adsorption. The catalytic activity was evaluated in the dehydration-dehydrogenation reaction of glycerol in the gas phase. In the iron oxide and nickel oxide catalysts, the result of $\mathrm{H}_{2}$-TPR showed that the presence of nickel influences the reduction of iron species. In the reaction, the catalysts showed similar conversion. However, the selectivity of the bimetallic oxide catalysts is modified, and the production of allyl alcohol increases noticeably forming a greater amount allyl alcohol than that observed in the monometallic oxides, in which a greater amount of hydroxyacetone is formed. The results indicate that the redox pairs $\mathrm{Fe}^{+3} / \mathrm{Fe}^{+2}$ influence the selectivity of these oxides. A decrease in the ratio $\mathrm{Fe}^{+3} / \mathrm{Fe}^{+2}$ species favored the formation of allyl alcohol.

Keywords: Iron oxides; glycerol; magnetite; hematite; allyl alcohol; $\mathrm{Fe}_{\mathrm{x}} \mathrm{O}_{\mathrm{y}}-\mathrm{NiO}$.

Resumen. Se presenta el estudio de catalizadores basados en óxidos de hierro y níquel (Fe, Ni y FeNi) soportados en una alúmina mesoporosa comercial. Los óxidos metálicos se sintetizaron por el método de impregnación de humedad incipiente. Las muestras se caracterizaron por XRD, TPR- $\mathrm{H}_{2}$, espectroscopía Raman, XPS y adsorción de $\mathrm{N}_{2}$. La actividad catalítica se evaluó en la reacción de deshidratación-deshidrogenación de glicerol en la fase gaseosa. En los catalizadores de óxido de hierro y óxido de níquel, el resultado de TPR- $\mathrm{H}_{2}$ mostró que la presencia de níquel influye en la reducción de las especies de hierro. En la reacción, los catalizadores mostraron una conversión similar. Sin embargo, la selectividad en los catalizadores de óxidos bimetálicos se modifica formando una mayor cantidad de alcohol alílico que la observada en los óxidos monometálicos, donde se forma una mayor cantidad de hidroxiacetona. Los resultados obtenidos indican que los pares redox $\mathrm{Fe}^{+2} / \mathrm{Fe}^{+3}$ influyen en el comportamiento catalítico de estos óxidos, en la selectividad. Una disminución de la relación $\mathrm{Fe}^{+3} / \mathrm{Fe}^{+2}$ favorece la formación de alcohol alílico.

Palabras clave: Óxidos de hierro; glicerol; magnetita; hematita; alcohol alílico; FexOy-NiO.
\end{abstract}




\section{Introduction}

Iron is known to be an active catalyst and a promoter in several catalytic reactions, such as the FisherTropsch synthesis [1], the oxidation of CO [2], Fenton-type reactions [3] and the water gas shift reaction [4]. Among the attractive properties of the iron-based catalysts are their activity, low cost, and redox properties.

It is known that iron can be present in different forms, such as isolated $\mathrm{Fe}^{+3} / \mathrm{Fe}^{+2}$ species, various forms of oxides, hydroxides or oxyhydroxides [5] and the identification of each one of them by a technique is not easy. In addition, through the thermal treatments a specific iron material can undergo changes that are not always visible. In the same way, during the reaction, intermediates with hydroxide groups can be formed that may affect the acidity of the catalytic surface and, consequently, modify the selectivity of the reaction mixture [6].

The glycerol, produced as a by-product in the soap and biodiesel industries, into more valuable chemicals such as acrolein, hydroxyacetone, 1,2 and 1,3-propanediol and esters, has been a matter of increased interest in the last decade.

F. Delgado et al. reported [7] that iron-based supported catalysts are active in the glycerol gas phase reaction producing a high proportion of acrolein. They also showed that nickel can influence the selectivity of iron catalysts improving the catalytic activity and modifying the selectivity. Nickel is also very active for oxidation and hydrogenation reactions since it adsorbs both oxygen and hydrogen under certain conditions. In addition, it can serve as a seed for a better dispersion of iron inducing a modification of the active surface [7]. For example, in the methane reforming reaction, the bimetallic NiFe catalyst turned out to be a more active catalyst than monometallic Ni, due to the stabilization of the metals in the bimetallic particles [4].

On the other hand, in the reductive amination of isopropanol it was observed that in $\mathrm{NiFe} / \gamma-\mathrm{Al}_{2} \mathrm{O}_{3}$ catalysts the nickel reducibility was affected by the iron species and, thus, the catalytic activity [8].

With respect the transformation of glycerol, De Oliveira et al. [9] studied the dehydration reaction of this compound with acid catalysts, such as zeolite $\beta$ and zeolite Y. They obtained mostly acrolein, and hydroxyacetone (acetol) in very small quantities. In this context, it is well known that the conversion and selectivity to acrolein or to hydroxyacetone is very dependent not only on the number and nature of the acid sites but also on the textural properties of the catalysts $[10,11]$. However, the major disadvantage of the vaporphase dehydration of glycerol to acrolein over acidic solid catalysts is carbon deposits [9]. To reduce carbon deposition, the addition of noble metals has been proposed. In this sense, Pd-HPW/Zr-MCM-21 showed higher acrolein selectivity, lower carbon deposition and higher stability than the catalysts without addition of Pd [12].

The direct conversion of glycerol to allyl alcohol is a less studied reaction. The allyl alcohol is an important chemical intermediate since it is very reactive due to presence of $\mathrm{C}=\mathrm{C}$ and $\mathrm{O}-\mathrm{H}$ functionalities. Allyl alcohol derivatives can be found in the cosmetic, pharmaceutical and food industries and are also raw materials for a wide variety of chemical products.

The production of allyl alcohol mainly involves the conversion of propylene; however, it can be obtained in a one-pot reaction from glycerol. This reaction can be achieved over iron catalysts in a two-step process: acrolein formation followed by the selective hydrogenation of the double bond in acrolein promoted by glycerol or other alcohols $[6,13,16,25]$. Catalysts such as zirconia-iron [13], $\mathrm{MoO}_{3}-\mathrm{WO}_{3} / \mathrm{TiO}_{2}$ [14], and vanadium supported zeolite beta [15] have been found to selectively catalyze the formation of allyl alcohol from glycerol. Sanchez G et al. [16] used ZSM-5 and alumina supported iron catalysts to promote the formation of allyl alcohol, and they found a correlation between the acid or basic sites concentration and the allyl alcohol selectivity, but the role of iron was no clear. It has been proposed that the iron species promote the formation of allyl alcohol through a hydrogen transfer reaction that may involve chemical intermediates from the dehydration of glycerol [15].

In reducible materials the changes in the oxidation state of the metallic species have an important effect on the acidic properties of the catalyst which in turn influences the deposition of surface carbon residues and, thus, the stability of the catalyst $[10,15]$. In reducible materials, then, both the acidic and redox properties influence the activity and the selectivity in the dehydration of glycerol.

In this work we evaluate the ability of iron oxides $\left(\mathrm{Fe}^{+2} / \mathrm{Fe}^{+3}\right.$ species), supported on a mesoporous alumina, and its modifications with nickel oxide, to produce allyl alcohol from the dehydration/dehydrogenation reactions of glycerol in the gas phase. 


\section{Experimental}

Supported iron oxides and nickel oxides were prepared by the conventional incipient wetness impregnation method using a commercial mesoporous $\mathrm{y}$-alumina (Sigma-Aldrich) as support. $\mathrm{Ni}\left(\mathrm{NO}_{3}\right)_{2} \cdot 6 \mathrm{H}_{2} \mathrm{O}$ and $\mathrm{Fe}\left(\mathrm{NO}_{3}\right)_{2} \cdot 9 \mathrm{H}_{2} \mathrm{O}$ were used as precursor salts (both from Sigma-Aldrich). For the monometallic oxide catalysts, the nickel or the iron loading was fixed at $3.8 \times 10^{-3}$ metal molar concentration ( $5 \mathrm{wt} \%$ metal loading) for $2 \mathrm{~g}$ of catalyst. The support was stirred with the required amount of an aqueous solution of the precursor salt at room temperature for $2 \mathrm{~h}$. These samples were denoted as (Fe/A) and (Ni/A). For the series of bimetallic oxides, three catalysts were prepared with variable $\mathrm{Fe} / \mathrm{Ni}$ molar ratio: $1 / 1(\mathrm{FeNi} / \mathrm{A}), 0.2 / 0.8\left(\mathrm{Fe}_{1} \mathrm{Ni}_{4}\right)$ and 0.8/0.2 $\left(\mathrm{Fe}_{4} \mathrm{Ni}_{1}\right)$. Then, the catalysts were dried at $100{ }^{\circ} \mathrm{C}$ overnight and calcined in air for $4 \mathrm{~h}$ at $400{ }^{\circ} \mathrm{C}$.

The samples were characterized by $\mathrm{N}_{2}$ adsorption-desorption isotherms (BET analysis), X-ray diffraction (XRD), Raman spectroscopy, X-ray photoelectron spectroscopy (XPS), temperature-programmed reduction with hydrogen $\left(\mathrm{H}_{2}\right.$-TPR) and FTIR spectroscopy of adsorbed pyridine.

The Brunauer-Emmett-Teller (BET) specific surface area, average pore diameter and pore volume were measured by a QuantachromeAutosorb-3B equipment using the nitrogen adsorption method. Prior to the measurements all samples were evacuated at $200{ }^{\circ} \mathrm{C}$ for $4 \mathrm{~h}$ at a pressure of $1.0 \times 10^{-3} \mathrm{kPa}$ to ensure complete removal of adsorbed moisture. radiation.

For the X-ray diffraction (XRD) experiments an X-ray diffractometer (Siemens) was used with $\mathrm{CuK}_{\square}$

All Raman spectra were recorded at room temperature with a Horiba Jobin-Yvon Lab Ram HR 800 micro-Raman system, equipped with an Olympus BX40 confocal microscope (Edison, NJ, USA) and a CCD detector (Edison, NJ, USA). Measurements were performed using an excitation wavelength of $532.1 \mathrm{~nm}$, a $50 \times$ objective, at a power close to $7 \mathrm{~mW}$ on the sample and 100 accumulations of $20 \mathrm{~s}$ per spectrum to improve the signal-to-noise $(\mathrm{S} / \mathrm{N})$ ratio. The spectra were calibrated using the $521 \mathrm{~cm}^{-1}$ line of monocrystalline silicon.

$\mathrm{H}_{2}$-TPR profiles were obtained by using an Altamira Instruments AMI-90; the samples (about 0.100 g) were pre-treated at $500{ }^{\circ} \mathrm{C}$ for $2 \mathrm{~h}$ under flowing nitrogen. A mixture of $10 \% \mathrm{v} / \mathrm{v} \mathrm{H}_{2} / \mathrm{Ar}(50 \mathrm{~mL} / \mathrm{min})$ and a $2{ }^{\circ} \mathrm{C} /$ min temperature ramp started from ambient temperature up to $900{ }^{\circ} \mathrm{C}$, were used.

Pyridine (Py) adsorption was followed by FTIR measurements with a BELCAT-B FTIR spectrometer (BEL Japan Inc.) using a home-made quartz cell, allowing sample vacuum $\left(\approx 10^{-5}\right.$ Torr) and temperature pretreatment $\left(400{ }^{\circ} \mathrm{C}, 1 \mathrm{~h}\right)$. Py was adsorbed on the sample at its vapor pressure in flowing nitrogen at $150{ }^{\circ} \mathrm{C}$ for $30 \mathrm{~min}$. Desorption data were collected at ambient temperature, $320^{\circ} \mathrm{C}$ and $400{ }^{\circ} \mathrm{C}$. Spectral bands at 1545 $\mathrm{cm}^{-1}$ (Brønsted sites) and $1450 \mathrm{~cm}^{-1}$ (Lewis sites) were considered for the estimation of acid sites concentration, using the molar extinction coefficients of $2.22 \mathrm{~cm} / \mu \mathrm{mol}$ (Lewis) and $1.67 \mathrm{~cm} / \mu \mathrm{mol}$ (Brønsted) [17].

XPS wide and narrow spectra were obtained with a JPS-9200 spectrometer from JEOL with a monochromatic $\mathrm{Al} \mathrm{K} \alpha \mathrm{X}$-ray source (energy $=1486.68 \mathrm{eV}$ ). In each elemental region, charge shift was adjusted using the binding energy of carbon (1s) peak centered at $285 \mathrm{eV}$ and used as internal standard to compensate for charge effects. Before the measurements, all samples were evacuated at ambient temperature for 8-10 h at a pressure of $1.0 \times 10^{-6}$ Torr. Each acquired spectrum were processed deconvoluting the peaks inside it.

The catalysts were evaluated in the reaction of glycerol in the gas phase at atmospheric pressure and temperature of $300^{\circ} \mathrm{C}$, using about $0.100 \mathrm{~g}$ of catalysts in a vertical fixed-bed reactor. Before each test, the catalyst was maintained for $1 \mathrm{~h}$ at $400{ }^{\circ} \mathrm{C}$ under a flux of nitrogen. The evaporator feed solution was $20 \% \mathrm{w} / \mathrm{w}$ glycerol-water, which was supplied by means of a piston pump with a rate of $3 \mathrm{~mL} \cdot \mathrm{h}^{-1}$. The carrier gas was nitrogen at a flow rate $15 \mathrm{~mL} \cdot \mathrm{min}^{-1}$. The reaction products were collected with a condenser under water and ice at $0{ }^{\circ} \mathrm{C}$. The reaction mixture was sampled every hour and analyzed in a Perkin-Elmer Clarus580 gas chromatograph equipped with a flame ionization detector and a capillary column Elite-Wax $(30 \mathrm{mx} 0.45 \mathrm{~mm})$. For these analyses the split ratio was $100: 1$. The injector temperature was $250^{\circ} \mathrm{C}$, detector temperature $300^{\circ} \mathrm{C}$, oven initial temperature $35{ }^{\circ} \mathrm{C}$ (for $5 \mathrm{~min}$ ) and then heated at rate of $10{ }^{\circ} \mathrm{C} / \mathrm{min}$ to $200{ }^{\circ} \mathrm{C}$ and holding this temperature for $20 \mathrm{~min}$. For quantitative measurements cyclohexanone was used as the internal standard. The reaction was carried out at a gas hourly space velocity (GHSV) of glycerol of $9 \mathrm{~h}^{-1}$. The GHSV was defined as the volume flow rate of vaporized glycerol at $300^{\circ} \mathrm{C}$ and $101.325 \mathrm{kPa}$ divided by volume of catalyst $(\mathrm{ca} .1 \mathrm{~mL})$. The molar rate at three hours of reaction (r) was calculated using the molar flow ratio, mass of the catalyst and 
the molar conversion of glycerol. The conversion of glycerol $(\% \mathrm{C})$ and the molar selectivity $(\% \mathrm{~S})$, were calculated as follows:

\section{Glycerol conversion $(\% \mathrm{C})=[(\text { reacted moles glycerol }) /(\text { moles glycerol in feed })]^{*} 100$}

\section{Product Selectivity $\left(\% \mathrm{~S}_{\mathrm{i}}\right)=[(\text { formed moles product } \mathrm{i}) /(\text { consumed moles glycerol })]^{* 100}$}

\section{Results and discussion}

The textural properties of the samples are shown in Table 1. No noticeable changes were observed in the textural properties of the $\mathrm{Fe} / \mathrm{A}$ and $\mathrm{Ni} / \mathrm{A}$ catalysts respect to the commercial support (A) therefore, the mesoporous structure is maintained. The $\mathrm{N}_{2}$-isotherm obtained from the $\gamma-\mathrm{Al}_{2} \mathrm{O}_{3}$ (not shown) is a type IV isotherm with a $\mathrm{H} 2$ hysteresis loop, indicating that calcined support exhibited mesoporous structure [8]. The specific surface area $\left(S_{B E T}\right)$ changes slightly, the pore diameters $\left(D_{p}\right)$ and the pore volumes $\left(V_{p}\right)$ decreases in the bimetallic oxides when the metals are incorporated to the support, which suggests that the impregnation of the nickel or iron species presumably blocks some pores of the alumina.

Table 1. Textural properties of samples.

\begin{tabular}{|c|c|c|}
\hline Samples & $\begin{array}{c}\text { Pore* } \\
\text { size/nm }\end{array}$ & $\begin{array}{c}\text { Surface } \\
\text { Área/m } / \mathbf{g}\end{array}$ \\
\hline $\mathrm{A}$ & 34.5 & 101.7 \\
\hline $\mathrm{Fe} / \mathrm{A}$ & 30.3 & 112.1 \\
\hline $\mathrm{Ni} / \mathrm{A}$ & 30.2 & 94.4 \\
\hline $\mathrm{FeNi} / \mathrm{A}$ & 21.9 & 115.3 \\
\hline $\mathrm{Fe}_{1} \mathrm{Ni}_{4} / \mathrm{A}$ & 17.7 & 112.9 \\
\hline $\mathrm{Fe}_{4} \mathrm{Ni}_{1} / \mathrm{A}$ & 17.5 & 113.9 \\
\hline
\end{tabular}

*Calculated by BJH method

The X-ray diffraction patterns (XRD) of the calcined catalysts in the mid-angle range are given in Fig. 1. The broadening of the XRD reflections indicates that the particle size of the catalysts is very small. Typical reflections of alumina $\left(\gamma-\mathrm{Al}_{2} \mathrm{O}_{3}\right)$ are observed (JCPDS 79-1558), in $2 \theta \approx 37.5^{\circ}, 45.7^{\circ}$ and $66.7^{\circ}$ [5]. The peaks at $2 \theta \approx 32^{\circ}$ and $38^{\circ}$ are assigned to the hematite phase of $\mathrm{Fe}_{2} \mathrm{O}_{3}$ as well as those of iron oxides $\left(\gamma-\mathrm{Fe}_{2} \mathrm{O}_{3}\right.$ and $\mathrm{Fe}_{3} \mathrm{O}_{4}$ ) (JCPDS 89-0597 and 88-0315). Reflections at $2 \theta \approx 44^{\circ}$ can be of a nickel oxide (NiO) phase (JCPDS 47-1049) interacting with iron species, the peaks of which overlap with those of alumina. No metallic Ni diffraction peaks are observed. The crystallite size of alumina was determined by the Scherrer equation [5], and the diffraction peak of alumina at $66.7^{\circ} 2 \theta$. No significant differences were observed in the values found (55 and $48 \AA$ ). So, the diffraction peaks and the crystallite size of the alumina phase in all samples suggest that the crystalline properties of the alumina are not affected by the metals. 


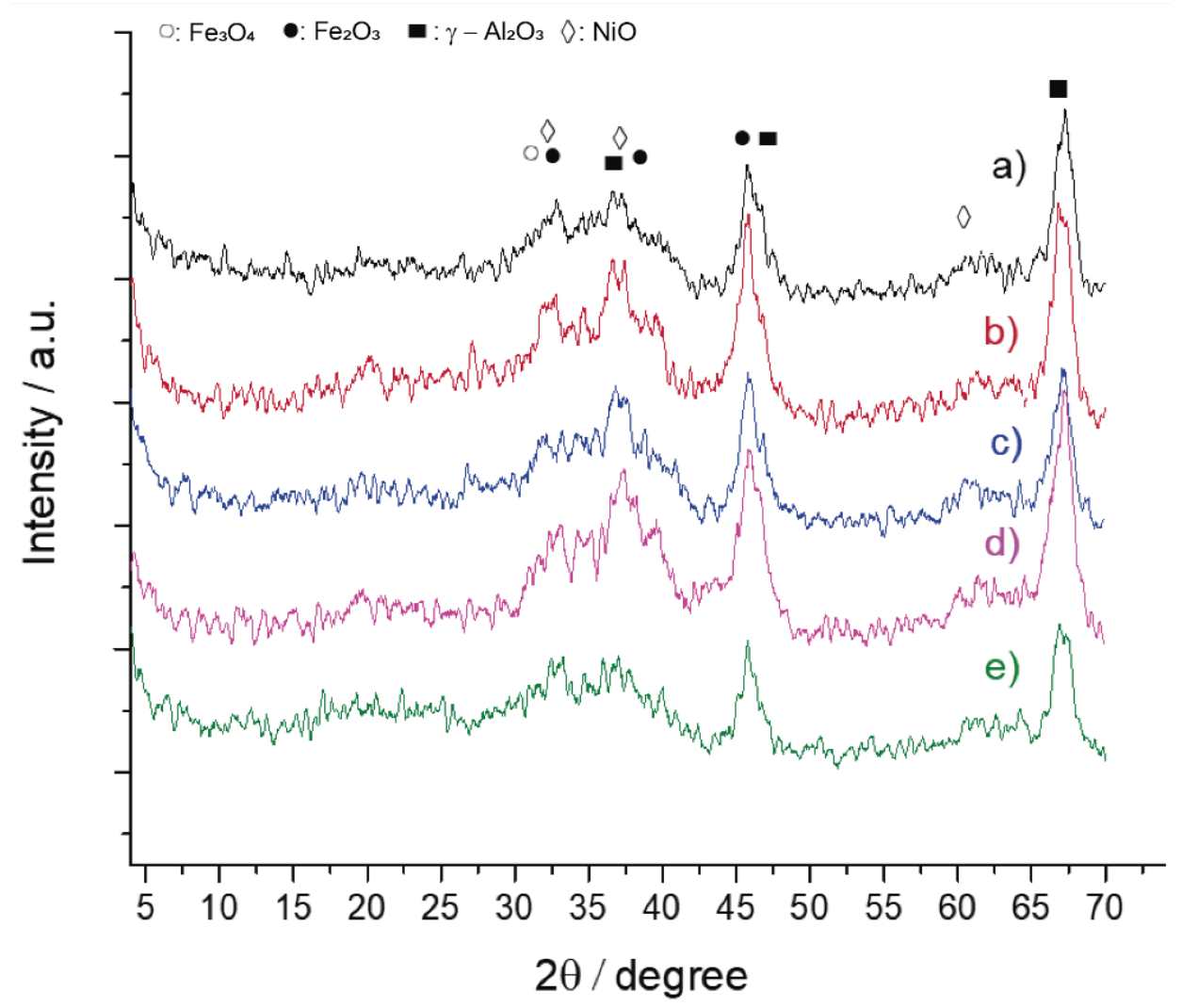

Fig. 1. Difractograms DRX of samples: a) $\mathrm{Fe} / \mathrm{A}$; b) Ni/A; c) $\mathrm{FeNi} / \mathrm{A}$; d) $\mathrm{Fe}_{1} \mathrm{Ni}_{4} / \mathrm{A}$; e) $\mathrm{Fe}_{4} \mathrm{Ni}_{1} / \mathrm{A}$.

The Raman spectra of the bimetallic oxide samples are shown in the Fig. 2. The figure shows distinct phases of iron oxide that are present in the samples, such as hematite $\left(\mathrm{Fe}_{2} \mathrm{O}_{3}\right)$, magnetite $\left(\mathrm{Fe}_{3} \mathrm{O}_{4}\right)$ and maghemite $\left(\gamma-\mathrm{Fe}_{2} \mathrm{O}_{3}\right)$ as well as nickel oxide $(\mathrm{NiO})$. The vibrational modes of magnetite, hematite and maghemite structures in Raman spectroscopy are summarized in Table 2. Some of the reported magnetite bands [18,19] are close to the values expected for hematite. These bands $\left(350,500\right.$ and $\left.700 \mathrm{~cm}^{-1}\right)$ are not well defined and a variation in its intensity is observed between the bimetallic samples depending if the oxides contain $\mathrm{Fe}^{+2}$ or $\mathrm{Fe}^{+3}$. The differences observed in the intensities of the peaks between monometallic and bimetallic oxides can be due to the lower content of iron in the bimetallic oxides and to the surface morphology of the catalysts. For $\mathrm{FeNi} / \mathrm{A}$ the strong band at $700 \mathrm{~cm}^{-1}$ suggests a greater presence of $\mathrm{Fe}_{3} \mathrm{O}_{4}$ in this catalyst. However, it is difficult to distinguish the oxidation state of these oxides since their crystallinity is low. 


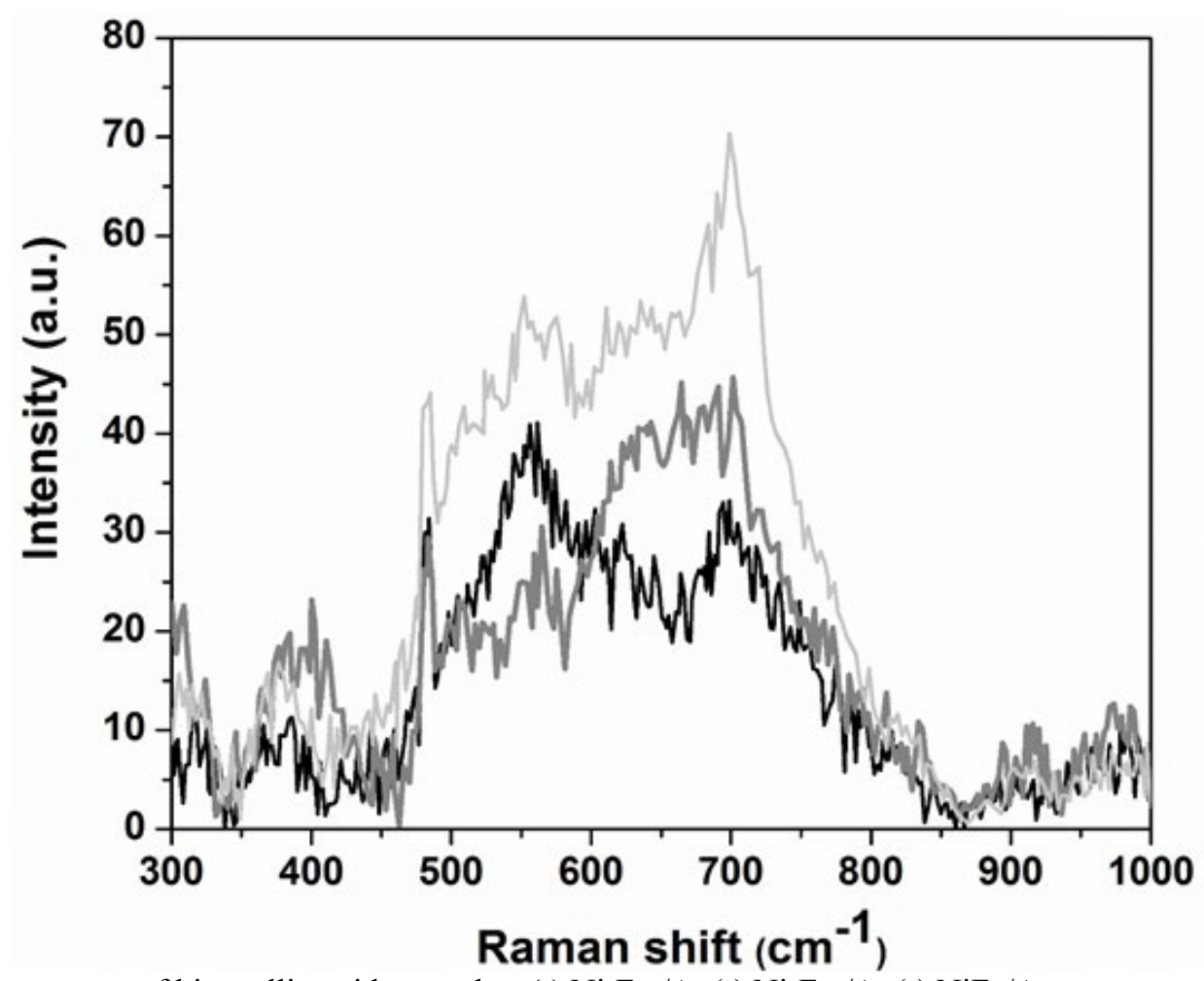

Fig. 2. Raman spectrum of bimetallic oxide samples: (-) $\mathrm{Ni}_{4} \mathrm{Fe}_{1} / \mathrm{A}$; (-) $\mathrm{Ni}_{1} \mathrm{Fe}_{4} / \mathrm{A}$; (-) $\mathrm{NiFe} / \mathrm{A}$.

Table 2. Wavenumbers (v) observed in the Raman spectrum of bimetallic samples.

\begin{tabular}{|l|l|l|l|}
\hline & $\boldsymbol{v}\left(\mathbf{c m}^{-\mathbf{1}}\right)$ & & Structural \\
\hline $\mathrm{Fe}_{1} \mathrm{Ni}_{4} / \mathrm{A}$ & $\mathrm{FeNi} / \mathrm{A}$ & $\mathrm{Fe}_{4} \mathrm{Ni}_{1} / \mathrm{A}$ & Observations \\
\hline 300 & 303 & 300 & magnetite \\
\hline 384 & 369 & 400 & nickel oxide \\
\hline 484 & 483 & 483 & hematite \\
\hline 556 & 552 & 564 & magnetite \\
\hline 694 & 698 & 701 & magnetite or maghemite \\
\hline 978 & 958 & 970 & nickel oxide \\
\hline 1045 & 1031 & 1039 & nickel oxide or maghemite \\
\hline
\end{tabular}

It has also been reported [18] that the oxyhydroxides $\left(\delta-\mathrm{FeOOH}, 300 \mathrm{~cm}^{-1}\right.$ y $\left.483 \mathrm{~cm}^{-1}\right)$ can show the characteristic peaks of hematite. Moreover, it is known that the Raman spectrum of FeO is very similar to that $\mathrm{Fe}_{3} \mathrm{O}_{4}$ [18], nevertheless $\mathrm{FeO}$ decomposes into magnetite under illumination. Transformation of magnetite, or maghemite, into hematite is a very common phenomenon in nature $[5,18,19]$. Still, analyzing the characteristic peaks of each sample, the Raman spectrum indicates a mixture of various phases and the proportions between them fluctuate along the series. For nickel there are two bands characteristic of $\mathrm{NiO}$ at $c a .400 \mathrm{~cm}^{-1}$ and 960 $\mathrm{cm}^{-1}$ [23]. 
To analyze the reducibility and the metal-support interactions, $\mathrm{H}_{2}$-TPR experiments were performed and the results are shown in the Fig. 3.

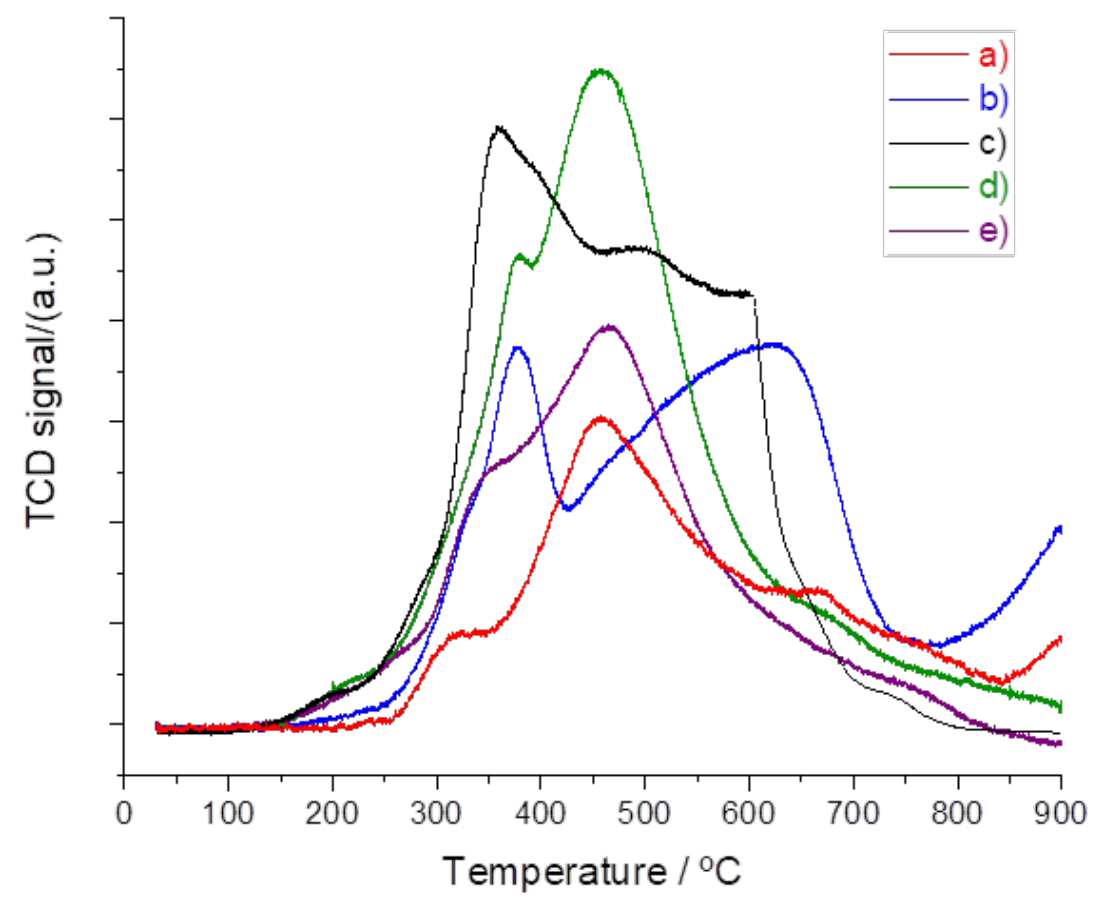

Fig. 3. $\mathrm{H}_{2}$-TPR of samples: a) Ni/A; b) $\mathrm{Fe} / \mathrm{A}$; c) $\mathrm{FeNi} / \mathrm{A}$; d) $\mathrm{Fe}_{4} \mathrm{Ni}_{1} / \mathrm{A}$; e) $\mathrm{Fe}_{1} \mathrm{Ni}_{4} / \mathrm{A}$.

The $\mathrm{H}_{2}$-TPR profile of the catalysts can be divided into three main regions (i.e., $\alpha, \beta, \gamma$, peaks, in Table 3 ): the first centered in the region of lowest temperature (peak $\alpha$ ) at $\approx 300-375{ }^{\circ} \mathrm{C}$, the second one (peak $\beta$ ) located at $\approx 450-575^{\circ} \mathrm{C}$ and the third (peak $\gamma$ ) centered at temperatures greater than $700{ }^{\circ} \mathrm{C}$.

Table 3. Evolved peak temperatures obtained from $\mathrm{H}_{2}-\mathrm{TPR}$ profiles.

\begin{tabular}{|c|c|c|c|}
\hline & & T/ & \\
\hline CATALYSTS & Peak $\boldsymbol{\alpha}$ & Peak $\boldsymbol{\beta}$ & Peak $\boldsymbol{\gamma}$ \\
\hline $\mathrm{Ni} / \mathrm{A}$ & 325 & 450 & $>700$ \\
\hline $\mathrm{Fe} / \mathrm{A}$ & 375 & 625 & $>700$ \\
\hline $\mathrm{Fe}_{1} \mathrm{Ni}_{4} / \mathrm{A}$ & 325 & 475 & --- \\
\hline $\mathrm{FeNi}_{4} / \mathrm{A}$ & 350 & 525 & --- \\
\hline $\mathrm{Fe}_{4} \mathrm{Ni}_{1} / \mathrm{A}$ & 375 & 450 & --- \\
\hline
\end{tabular}

The profiles of the monometallic oxide catalysts, Ni/A and Fe/A, show two hydrogen consumption peaks in the region $\alpha$ and $\beta$, due to the reduction of $\mathrm{NiO}$ species $\left(\mathrm{Ni}^{+2} \rightarrow \mathrm{Ni}^{0}\right)$ that do not interact with the support, and to the reduction of iron oxide species -first $\mathrm{Fe}_{2} \mathrm{O}_{3}$ and then $\mathrm{Fe}_{3} \mathrm{O}_{4}$ to $\mathrm{FeO}$ [22]. Furthermore, the peak that starts at temperatures greater than $700{ }^{\circ} \mathrm{C}$ (peak $\gamma$ ), can be attributed to the reduction of $\mathrm{FeO}$ to $\mathrm{Fe}[6$, 22] and to the reduction of $\mathrm{NiAl}_{2} \mathrm{O}_{4}$ spinels [23]. 
Both $\mathrm{Ni}$ and Fe suffer modifications of their reduction behavior when they are in combination with the second metal oxide. One of these is the high temperature region in the bimetallic catalysts; it can be observed that there is no consumption of hydrogen indicating that the Ni species that are strongly interacting with the support are either not present on the bimetallic samples or are reduced at much lower or much higher temperatures. In a similar manner one can think that the reduction of $\mathrm{FeO}$ to $\mathrm{Fe}$ is either proceeding at a lower temperature or at a much higher one, but since no metallic iron was observed in the XRD patterns, it has to be concluded that the reduction of $\mathrm{FeO}$ occurs at temperatures greater than $700{ }^{\circ} \mathrm{C}$.

On the other hand, the low temperature profile of the bimetallic oxides catalysts is very different from that of the monometallic ones. The first reduction peak $(\alpha)$ of the Ni/A catalysts appears at $325{ }^{\circ} \mathrm{C}$ and in the other samples this peak is present at either $325^{\circ} \mathrm{C}$ or at a higher temperature. In the bimetallic oxides the second reduction peak $(\beta)$ of $\mathrm{FeNi} / \mathrm{A}$ is very different from the other samples. The reduction processes in the bimetallic samples begin 100 degrees before the reduction processes of Fe/A. This implies that the presence of nickel oxide favors the reduction processes of iron species in the bimetallic oxide samples and this may be an important factor to consider in the catalytic activity of these solids. Such a profile modification in the bimetallic samples may be due to an interaction between the two oxides and this may produce active redox pairs.

Fig. 4 shows the Fe $2 p$ XPS spectra of $\mathrm{Fe} / \mathrm{A}$, where three doublets were observed (and the corresponding satellite peaks) with binding energies for the first doublet peaking close to 706 and $715 \mathrm{eV}$, the second doublet with peaks close to 710 and 719 and the third doublet with peaks at 712 and $722 \mathrm{eV}$, which were attributed to $\mathrm{Fe}, \mathrm{Fe}^{+2}$ and $\mathrm{Fe}^{+3}$, respectively [20].

For the bimetallic oxides, the $\mathrm{Fe} 2 \mathrm{p}$ peaks were shifted to higher binding energies, and this may be explained by an enhanced electron density of the Fe species due to the presence of nickel (Table 4) [3, 22]. In the Ni 2p XPS spectra (not showed), even when a lot of noise was observed and, also, low intensities, two peaks located at $\approx 855$ and $871.6 \mathrm{eV}$ were detected, corresponding to $\mathrm{Ni}^{+2}$ from $\mathrm{NiO}$ and $\mathrm{Ni}^{+2}$ peaks at 857 and 873.4 $\mathrm{eV}$ from $\mathrm{NiAl}_{2} \mathrm{O}_{4}$ spinel structure, respectively [23].

From the spectra, the relative amounts of the iron species in the monometallic and the bimetallic oxides were obtained. These results are shown in table 4. The data indicate that iron species including $\mathrm{Fe}, \mathrm{Fe}_{2} \mathrm{O}_{3}$ and $\mathrm{Fe}_{3} \mathrm{O}_{4}$ coexisted in all samples. The first two species are in greater proportion in $\mathrm{Fe} / \mathrm{A}$ sample, while in the bimetallic oxides this proportion changes.

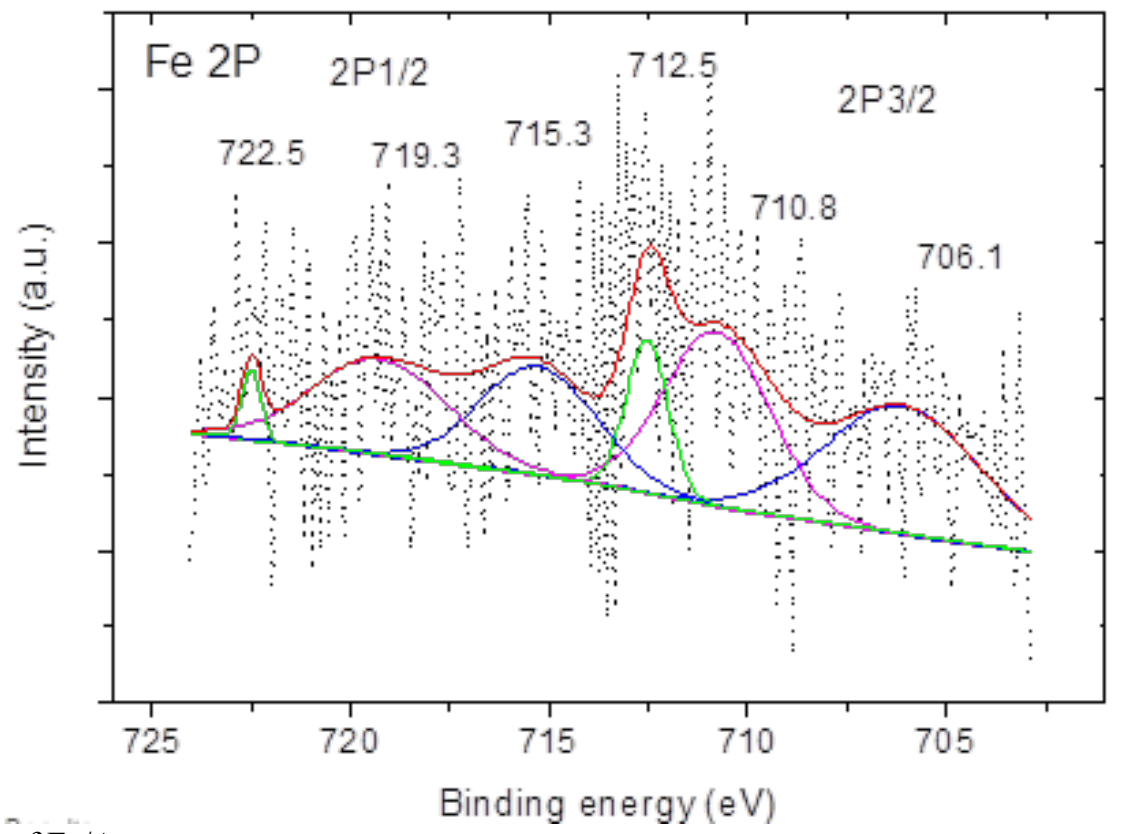

Fig. 4. XPS spectra of Fe/A. 
Table 4. Binding energy (BE) and percentage composition of the XPS spectra.

\begin{tabular}{|c|c|c|c|c|c|c|c|}
\hline \multirow[b]{2}{*}{ Catalysts } & \multicolumn{2}{|c|}{$\begin{array}{c}\text { First } \\
\text { double } \\
\text { BE (eV) }\end{array}$} & \multicolumn{2}{|l|}{$\begin{array}{l}\text { Second } \\
\text { double } \\
\text { BE }(\mathrm{eV})\end{array}$} & \multicolumn{2}{|l|}{$\begin{array}{c}\text { Third } \\
\text { double } \\
\text { EB }(e V) \\
\end{array}$} & \multirow{2}{*}{$\mathrm{Fe}^{+3} / \mathrm{Fe}^{+2}$} \\
\hline & $\mathrm{Fe}$ & $(\mathrm{Fe} 2 \mathrm{p})$ & $\mathrm{Fe}_{2} \mathrm{O}_{3}$ & $\left(\mathrm{Fe} 2 \mathrm{p}_{3 / 2}\right)$ & $\mathrm{Fe}_{3} \mathrm{O}_{4}$ & $\left(\mathrm{Fe} 2 \mathrm{p}_{1 / 2}\right)$ & \\
\hline $\mathrm{Fe} / \mathrm{A}$ & 706.1 & 715.3 & 710.8 & 719.3 & 712.5 & 722.5 & \\
\hline$\%$ & & 44.47 & & 44.69 & & 10.84 & 4.12 \\
\hline $\mathrm{Fe}_{1} \mathrm{Ni}_{4} / \mathrm{A}$ & 714.1 & 722.1 & 717.37 & 725.15 & 719.47 & 727.47 & \\
\hline$\%$ & & 43.32 & & 39.33 & & 17.33 & 2.27 \\
\hline $\mathrm{FeNi} / \mathrm{A}$ & 711.3 & 728.3 & 715.7 & 730.4 & 718.7 & 734.6 & \\
\hline$\%$ & & 31.44 & & 34.46 & & 34.07 & 1.01 \\
\hline $\mathrm{Fe}_{4} \mathrm{Ni}_{1} / \mathrm{A}$ & 711.8 & 717.6 & 713.9 & 724.7 & 721.7 & 727.6 & \\
\hline$\%$ & & 29.75 & & 36.43 & & 33.78 & 1.08 \\
\hline
\end{tabular}

The results for the bimetallic oxides show that although the presence of $\mathrm{Ni}$ can promote the reduction of the iron species, these remained mostly in their oxide forms, i. e., $\mathrm{Fe}_{2} \mathrm{O}_{3}, \mathrm{Fe}_{3} \mathrm{O}_{4}, \mathrm{FeO}$ and $\mathrm{NiO}$ as confirmed by Raman analyses and $\mathrm{H}_{2}$-TPR measurements.

According to the literature $[10,11,22]$ in bimetallic oxides NiFe catalysts, the reduction temperature of nickel is displaced to lower values by an interaction with the iron species. In addition, the metals species may also interact with the alumina support. However, the reduction of iron oxides at lower temperature in the $\mathrm{NiFe} / \mathrm{A}$ may suggest that the addition of nickel oxide promotes the reduction of iron oxide particles, as reported in [23]. Nevertheless, in our samples the presence of iron oxide species was confirmed through Raman, XPS, and the $\mathrm{H}_{2}$-TPR analyses. By XPS, the monometallic catalyst Fe/A showed a higher ratio $\mathrm{Fe}^{+3} / \mathrm{Fe}^{+2}$ pairs than the bimetallic oxide catalysts.

The acidic properties of the samples were measured by pyridine adsorption taking into consideration the bands at approximately 1550,1480 and $1450 \mathrm{~cm}^{-1}$ attributed to Lewis acid sites and the bands at 1530 and $1645 \mathrm{~cm}^{-1}$ attributed to Brønsted acid sites [24]. In all the samples the bands disappear at $400{ }^{\circ} \mathrm{C}$, i.e., highstrenght acid sites are not present. In table 5, the concentrations of Lewis and Brønsted sites acid measured with the desorption of Py at $320^{\circ} \mathrm{C}$ are shown. The amount of Brønsted acid sites on $\mathrm{Fe} / \mathrm{A}$ and $\mathrm{Fe}_{1} \mathrm{Ni}_{4} / \mathrm{A}$ are higher than in the other samples. But there is no trend of the medium strength acidity $\left(320^{\circ} \mathrm{C}\right)$ within the various catalysts, except for the Brønsted molar fraction which increases with the nickel content in the bimetallic samples. Nevertheless, it is evident that the addition of nickel impacts the acid properties of the catalysts, altering the concentration of the acid sites $\left(\mathrm{C}_{B} /\left(\mathrm{C}_{B}+\mathrm{C}_{\mathrm{L}}\right)\right)$ by possible structural changes of the bimetallic oxides.

Table 5. Concentration of acid sites, Lewis $\left(\mathrm{C}_{\mathrm{L}}\right)$ and Brønsted $\left(\mathrm{C}_{\mathrm{B}}\right)$, by desorption of Py at $320^{\circ} \mathrm{C}$.

\begin{tabular}{|c|c|c|c|c|}
\hline Catalysts & $\mathbf{F e} / \mathbf{A}$ & $\mathbf{F e} 4 \mathbf{N i}_{1} / \mathbf{A}$ & $\mathbf{F e N i} / \mathbf{A}$ & $\mathbf{F e}_{1} \mathbf{N i}_{4} / \mathbf{A}$ \\
\hline $\mathrm{C}_{\mathrm{L}}(\mu \mathrm{mol} / \mathrm{g})$ & 18.02 & 347.22 & 39.41 & 178.33 \\
\hline $\mathrm{C}_{\mathrm{B}}(\mu \mathrm{mol} / \mathrm{g})$ & 152.7 & 38.92 & 4.99 & 170.67 \\
\hline $\mathrm{C}_{\mathrm{B}} /\left(\mathrm{C}_{\mathrm{B}}+\mathrm{C}_{\mathrm{L}}\right)$ & 0.89 & 0.10 & 0.11 & 0.49 \\
\hline
\end{tabular}

The catalysts were evaluated in the transformation of glycerol in the gas phase. The conversion $(\% \mathrm{C})$, rate $(\mathrm{r})$ and the molar selectivity $(\% \mathrm{~S})$ values were obtained at $3.0 \mathrm{~h}$ of reaction, WHSV: $9 \mathrm{~h}^{-1}$ and $300{ }^{\circ} \mathrm{C}$ and are shown in Table 6. It is observed that $\mathrm{Ni} / \mathrm{A}$ is more active than $\mathrm{Fe} / \mathrm{A}$. While in the bimetallic oxides there are differences between them observing a lower activity in the $\mathrm{FeNi} / \mathrm{A}$. However, under similar reaction conditions $\left(340^{\circ} \mathrm{C}\right.$, WHSV: $3 \mathrm{~h}^{-1} ; 30 \mathrm{wt} \%$ glycerol) the value obtained in our work $(\mathrm{ca} .90 \% \mathrm{C})$ is in agreement with that reported for a $\gamma-\mathrm{Al}_{2} \mathrm{O}_{3} / \mathrm{Fe} / \mathrm{Rb}$ catalyst $(90 \% \mathrm{C})[25]$. 
Under our reaction conditions the main products were acrolein (AC), allyl alcohol (AA), hydroxyacetone (HA), and other liquid and gaseous compounds that were not identified. However, the molar selectivity (\%) that we report is normalized. As regards to the selectivity, notable differences are observed between the monometallic oxide and the bimetallic oxide catalysts.

Table 6. Rates (r) and molar Selectivities (\%S) over the glycerol reaction. AA: allyl alcohol; AC: acrolein; HA: hydroxyacetone. (Reaction conditions: T: $300{ }^{\circ} \mathrm{C}, \mathrm{P}: 1 \mathrm{~atm} ; \mathrm{t}_{\mathrm{R}}: 3 \mathrm{~h}$ ).

\begin{tabular}{|l|l|l|l|l|}
\hline & \multicolumn{1}{|c|}{$\mathbf{r} \times \mathbf{1 0}^{\mathbf{4}}$} & & $\mathbf{\% S}$ & \\
\hline Catalysts & $\mathbf{m o l G l y c} / \mathbf{s . g}$ & $\mathbf{A A}$ & $\mathbf{A C}$ & $\mathbf{H A}$ \\
\hline $\mathrm{Fe} / \mathrm{A}$ & 2.97 & 0 & 13.62 & 86.38 \\
\hline $\mathrm{Fe}_{4} \mathrm{Ni}_{1} / \mathrm{A}$ & 3.07 & 63.46 & 5.12 & 31.42 \\
\hline $\mathrm{FeNi} / \mathrm{A}$ & 2.92 & 90.97 & 9.03 & 0 \\
\hline $\mathrm{Fe}_{1} \mathrm{Ni}_{4} / \mathrm{A}$ & 3.16 & 0 & 12.20 & 87.80 \\
\hline $\mathrm{Ni} / \mathrm{A}$ & 3.120 & 0 & 17.71 & 82.29 \\
\hline
\end{tabular}

The Ni/A, Fe/A and $\mathrm{Fe}_{1} \mathrm{Ni}_{4} / \mathrm{A}$ samples produce higher amounts of hydroxyacetone, while the bimetallic oxide catalysts with the greater amounts of iron, $\mathrm{FeNi} / \mathrm{A}$ and $\mathrm{Fe}_{4} \mathrm{Ni}_{1} / \mathrm{A}$, show an increase in the selectivity of allyl alcohol at the expense of hydroxyacetone. These two catalysts present the lowest molar fraction of Brønsted sites (Table 5), and the highest concentration of $\mathrm{Fe}^{2+}$ species (Table 4). These facts may point out the importance of redox sites in the selectivity of the bimetallic catalysts with lower amounts of nickel.

Lang et al [25] reported the effect of adding Fe-Mo species to KIT-6 silica. FeMo-KIT-6 bimetallic catalyst presented a much higher selectivity than the monometallic Mo-Kit-6. This is explained by a strong synergetic effect between $\mathrm{Fe}_{2} \mathrm{O}_{3}$ and $\mathrm{MoO}_{3}$ which alters the surface, moderate acid strength, the number of acid sites and the reducibility of the surface species. Also, a synergetic effect was observed in Fe-Mo/HZSM-5 catalysts and $\mathrm{FeO}_{\mathrm{x}} / \mathrm{NiO}_{\mathrm{y}} / \mathrm{SBA}-15$, the latter showing a positive contribution of the nickel species $[3,26]$. Therefore, it is clear that the allyl alcohol selectivity and glycerol conversion are strongly dependent on the acid-base and redox properties of the catalysts $[10,26]$.

Glycerol is a very reactive molecule due to the presence of primary and secondary hydroxyl groups that can be replaced by other functionalities. According to most of the literature [6] the dehydration reaction occurs mainly in the presence of acid sites, while in the presence of metals, hydrogenation or hydrogenolysis may occur due to the breakdown of $\mathrm{C}-\mathrm{O}$ bonds or $\mathrm{C}-\mathrm{C}$ bonds in the glycerol molecule.

The formation of allyl alcohol can happen by two stages; first, the dehydration of glycerol to form acrolein with the participation of acid sites, followed by another hydrogenation (redox sites or Lewis sites) to form allyl alcohol [15,27]. However, a hydrogen source is required to allow the dihydroxylation needed to obtain allyl alcohol. It should be mentioned that in both routes there is the formation of an enol intermediate, which could be determined by the ratio of the Brønsted/Lewis acid or redox sites involved in the reaction $[6,10,21]$.

Martinuzzi et al. [21] and Liu et al. [6] relate acrolein and allyl alcohol formation to one synthesis route, while the formation of hydroxyacetone follows a different path. It is proposed that the Brønsted acid sites lead to acrolein production, while the Lewis acid or redox sites produces mainly hydroxyacetone by means of the enol intermediate $[6,10]$. The $\mathrm{Fe}_{\mathrm{x}} \mathrm{O}_{\mathrm{y}}$ plays an important role in providing redox sites for this reaction. So, the pathway proposed by G. Sanchez et al. $[16,27]$ for the allyl alcohol formation is consistent with our results for the bimetallic oxide samples, since its formation is attributed to a consecutive reaction in which the enol intermediate formed on the redox sites $\left(\mathrm{Fe}^{+3} / \mathrm{Fe}^{+2}\right.$ in this work), results in a higher selectivity to allyl alcohol (Fig. 5). 


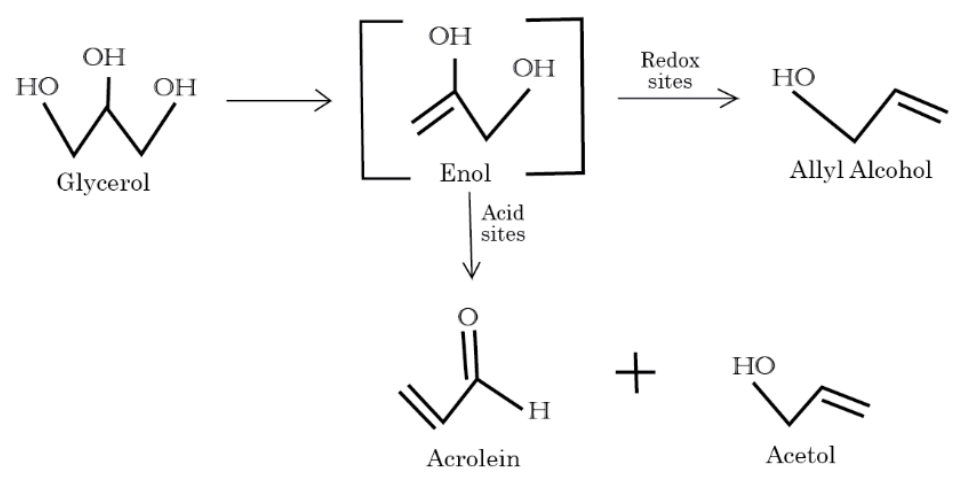

Fig. 5. Possible reaction pathways from glycerol to allyl alcohol.

The changes observed in the selectivity of our catalysts can be attributed to the presence of various ratios of $\mathrm{Fe}^{+3} / \mathrm{Fe}^{+2}$, obtained by XPS, Raman, and TPR- $\mathrm{H}_{2}$ experiments, and supports the proposal to include the redox pairs in the reaction mechanism. This suggests that a decrease in the $\mathrm{Fe}^{+3} / \mathrm{Fe}^{+2}$ ratio favors the formation of allyl alcohol.

\section{Conclusions}

The textural properties of the support, obtained by nitrogen physisorption, did not show notable differences with the catalysts, indicating that the mesoporous nature of the support was not altered by the deposition of the metals.

The XRD diffractograms, XPS, and Raman spectra of the catalysts revealed the presence of nickel oxide (NiO) and iron oxide $\left(\mathrm{Fe}_{3} \mathrm{O}_{4}\right.$ and $\left.\mathrm{Fe}_{2} \mathrm{O}_{3}\right)$ phases, i.e. the presence of $\mathrm{Fe}^{+3} / \mathrm{Fe}^{+2}$ pairs.

In the analysis of the reduction profiles $\left(\mathrm{H}_{2}\right.$-TPR), it was observed that the reduction behavior of both $\mathrm{Ni}$ and Fe was altered by the presence of the second metal in the samples, reducing the temperature that initiates the reduction processes and modifying the reduction of the nickel aluminates and of $\mathrm{FeO}$.

All the catalysts were found to have similar activities with notable differences in their selectivity. These differences are explained by the interaction between the metal oxides in the bimetallic catalysts, which produces changes in the $\mathrm{Fe}^{+3} / \mathrm{Fe}^{+2}$ ratio. The production of allyl alcohol on the bimetallic oxides may be explained by the redox properties of these catalysts. A decrease in the $\mathrm{Fe}^{+3} / \mathrm{Fe}^{+2}$ ratio, favors the formation of allyl alcohol.

\section{Acknowledgemnsts}

The authors are grateful for financial support of UAM-I-CA-156 of PRODEP-SEP. We also thank to Dr. Michel Picquart (UAMI) for the Raman spectra of samples, Dra. Aída Gutiérrez (UNAM) for the experiments with pyridine adsorption and to Dra. Iris Serratos (UAMI) for the help in the elaboration of the figures.

\section{References}

1. Feyzi, M.; Mirzaei, A.A. Petroleum Chemistry 2012, 5, 362-371. DOI: /10.113/SO96554411205002.

2. Dreyer, J.A.H.; Grossmann, H.K.; Chen, J.; Greb, T.; Gong, B.B.; Sit, P.H.L.; Madler, L.; Teoh, L. Y. J. of Cat. 2015, 329, 248-261. DOI:/10.1016/j.jcat2015.5.003. 
3. Li, X.; Liv, W.; Ma, J.; Wen, Y.; Wu, Z. Appl.Catal B. 2015, 179, 239-248. DOI: /10 1016/apcatb.2015.05.034.

4. Margossian, T.; Larnier, K.; Kumeich, F.; Muller, C.; Coperet, C. ACS Catalysis 2017, 7, 6942-6948. DOI: /10.1021/acscatal.7b02091.

5. Lubbe, M.; Gigler, A.M.; Stark, R.W.; Moritz, W. Surface Science 2010, 604, 679-685. DOI: /10.1016/j.susc.2010.01.015.

6. Liu, Y.; Tuysuz, H.; Jia, Ch. J.; Schwickardi, M.; Rinaldi, M.; Lu, A.H.; Schmidt, W.; Shut, F. Chem. Comm. 2010, 46, 1238. DOI: /10.139/b921648k.

7. García-Delgado, F.J.; Viniegra, M.; Córdoba, G.; Martín, N. Actas XXV CICAT 2016, P447, Montevideo, Uruguay.

8. Hong, E.; Bang, S.; Cho, J.H.; Jung, K.D.; Shin, C.H. Appl. Catal. A. 2017, 542, 146-153. DOI: /10.1016/j.apcata.2017.05.003.

9. De Oliveira, A.S.; Vasconcelos, S.T.; De Sousa, J.R.; Filho, J.M; Oliveira, A.E. Chem. Eng. J. 2011, 168, 765. DOI: /10.1016/j.cej.2020.09.029.

10. Santos, R.C.R.; Braga, D.M.V.; Pinheiro A.N.; Freire, V.N.; Longhinotti; Valentini A. Catal. Sci. \&Tecnology 2016, 6, 4986-5002. DOI: /10.1039/c6cy0096g.

11. Martínez-Rico, M.; Aguilar-Pliego, J.; Pérez-Pariente, J.; Márquez, C.; Viniegra, M.; Martin, N. RMIQ 2018, 17, 523-532. DOI: /10.24275/uam/izt/dcbi/ revmexingquimica/ 2018v17n2/Martinez/.

12. Ma, T.L.; Yun, Z.; Xu, W.; Chen, L.G.; Li, L.; Ding, J.F.; Shan, R. Chem. Eng. J. 2016, 294, 343-352.

13. Yoshikawa, T.; Tago, T.; Nakamura, A.; Konaka, A.; Mukaida, M.; Masuda, T. Res. Chem. Intermed. 2011, 37, 1247-1256. DOI: /10.1007/s1164-011-0391-y.

14. Ulgen, A.; Hoelderich, W.F. Applied Catalysis A: Gen. 2011, 400, 34-38. DOI: 10.1016 /j.apcata.2011.04.005.

15. Almeida, R.; Filipa Ribeiro, M.; Fernandes, A.; Lourenco, J.P. Catalysis Communication 2019, 217, 20-24. DOI: 10.1016/j.catcom.2019.04.015.

16. Sánchez, G.; Dlugogorski, B.Z.; Kennedy, E.M.; Stockenhuber, M.. Applied Catalysis: A. 2016, 519, 130-142. DOI: /10.1016/apcata.2015.09.039.

17. Emeis, C.A. J. of Cat. 1993, 141, 347-354. DOI: 0021.9517.

18. de Faira, D.L.A.; Venancio Silva, S.; Oliveira, M.T. J. of Raman Spectroscopy 1997, 28, 873-878. DOI: CCC 0377-0486/97/110873-06.

19. Gerónimo-López, C.; Vázquez-Arenas, J.; Picquart, M.; González, I. Electrochimica Acta 2014, 136, 146-156. DOI: /10.1016/j.electacta.2014.05.069.

20. Wu, D.; Zhang, Y.; Wen, M.; Fang, H.; Wu, Q.. Inorganic Chemistry 2017, 5152-5157. DOI: /10.1021/acs.inorg.chem.7b00304.

21. Martinuzzi, I.; Azizi, Y.; Davaux, J.F.; Tretjak, S.; Zahraa, O.; Leclerk, J.P. Chem. Eng. Sci, 2014, 116, 118-127. DOI: /10.1016/j.ces.2014.04.030.

22. Jin, Y.M.; Datye, A.K. J. of Cat. 2000, 196, 8-17. DOI: /10.1006/jcat.2000.3024.

23. Tian, D.; Liu, Z.; Li, D.; Shi, H.; Pan, W.; Chang, Y. Fuel. 2013, 104, 224-229. DOI: /10.1016/j.fuel.2012.08.033.

24. Topaloglu-Yazici, D.; Bilgic, C. Surf. Interface Anal. 2010, 42, 959-962. DOI: /10.1002/sia.3474.

25. Lang, H.; Xiao, X.; Yuan, S.; Xhang, B.; Zhou, G.; Yiang, Y. Catal. Letters 2017, 147, 2187-2199. DOI:/10.107/s10562-017-2124-3

26. A. Kostyniuk, D. Bajec, P. Djinovic and B. Likozar. Chem. Eng. Journal, 2020, 397, 125430. DOI:/10.1016/j.cej.2020.125430.

27. G. Sánchez, J. Friggieri, C. Keast, M. Drewery, B.Z. Dlugogorski, E. Kennedy and M. Stockenhuber. Appl. Catal. B, 2014, 152-153, 117-128. DOI:/10.1016/ j.apcatb.2014.01.019. 